\title{
Pemberian Ekstrak Air Panas Spirulina platensis melalui Perendaman Terhadap Total leukosit, Indeks fagositosis dan konsentrasi TNF-a Osphronemous gouramy
}

\author{
Myrna Budi Resmawati*1, Woro Hastuti Satyantini ${ }^{2}$, Hari Suprapto ${ }^{3}$ \\ ${ }^{1,2}$ Universitas Airlangga; Mulyorejo, telp/fax of institution/affiliation \\ ${ }^{3}$ Prodi S2 Bioteknologi Perikanan dan kelautan, Pascasarjana Unair, Surabaya. \\ e-mail: *1 myrnabudi@ymail.com $^{1}$
}

\begin{abstract}
ABSTRAK
Penelitian ini bertujuan untuk mengetahui pengaruh imunostimulan ekstrak air panas Spirulina (Spirulina platensis) pada ikan gurame Osphronemous gouramy. Pada penelitian ini ekstrak air panas Spirulina diuji apakah dapat meningkatkan mekanisme non- spesifik melalui parameter total leukosit, indeks fagositosis dan konsentrasi TNF- $\alpha$ pada hari ke 3, 5, 7dan 14 setelah perendaman ekstrak air panas Spirulina dengan dosis 15 ppm, 30 ppm, 60 ppm dan tanpa imunostimulan (kontrol) selama 3 jam. Hasil penelitian menunjukkan ekstrak air panas Spirulina dapat meningkatkan total leukosit dan indeks fagositosis pada darah dan konsentrasi TNF- $\alpha$ pada serum darah. Data dianalisis menggunakan Analisis Varian dilanjutkan dengan Duncan. Pada hasil menunjukkan ekstrak air panas Spirulina dapat meningkatkan total leukosit, indeks dan konsentrasi TNF- $\alpha(P<0.05)$. Ekstrak air panas Spirulina dengan dosis 30 ppm dapat meningkatkan total leukosit dan indeks fagositosis pada hari keempat belas dan konsentrasi TNFa pada hari ke tujuh dbandingkan kontrol. Ekstrak air panas Spirulina dapat memberikan pengaruh pada imun non-spesifik ikan gurame.
\end{abstract}

Kata kunci: Osphronemus gouramy, ekstrak air panas, Spirulina platensis

\begin{abstract}
Immunostimulant effects of the Hot Water Extract Spirulina (Spirulina platensis) were studied in Osphronemous gouramy. For this purpose, fish were immersion in Hot Water Extract Spirulina and the parameters of non-specific defence mechanisms, including WBC, index phagocytosis and TNF- $\alpha$ concentration were performed at 3, 5, 7 and 14 days after Hot Water Extract Spirulina administration. The treatment was bathing of hot water extract of S. platensis with doses of 15 ppm, 30 ppm, 60 ppm and without immunostimulant (control) in 3 hours The results showed that Hot Water Extract Spirulina enhanced responses of WBC and index phagocytosis in blood and TNF- $\alpha$ concentration in blood serum. Data were analyzed by Analysis of Variance followed by Duncan's Multiple Range Test (DMRT). The results showed that Hot Water Extract Spirulina could increase $W B C$, index phagocytosis and TNF- $\alpha$ concentration $(P<0.05)$ of gouramy fish. The addition of hot water extract of $S$. platensis at 30 ppm gave WBC an index phagocytosis on days 14 and TNF- $\alpha$ concentration on days 7 higher than control. Hot Water Extract Spirulina has immunostimulatory effects on the innate immune system of gouramy fish.
\end{abstract}

Keywords: Osphronemus gouramy, hot water extract, Spirulina platensis 


\section{PENDAHULUAN}

Gurame merupakan salah satu ikan konsumsi air tawar yang populer dan banyak dibudidayakan di Indonesia. Ikan gurame berasal dari genus Osphronemus. Salah satu penyakit yang banyak menyebabkan kematian ikan gurame adalah Motile Aeromonas septisemia (MAS) yang disebabkan oleh bakteri Aeromonashydrophila. Kematiannya dapat mencapai waktu singkat yaitu 80-100\% dalam 1-2 minggu (Kamiso dan Triyanto, 1993). Pengendalian penyakit yang disebabkan oleh A.hydrophila biasanya dilakukan dengan pemberian antibiotika seperti chloramphenicol, terramicyn atau oxytetracyclin dengan dosis sebanyak 5-7 gram $/ \mathrm{kg}$ pakan namun penggunaan antibiotika saat ini dilarang sebab dapat menimbulkan resistensi bakteri A.hydrophila terhadap antibiotik tertentu.

Salah satu solusi untuk menghindari dampak negatif dari penggunaan antibiotik adalah dengan penggunaan immunostimulan. Immunostimulan merupakan senyawa kimia, obat atau bahan lain yang mampu meningkatkan mekanisme respons imun spesifik dan non spesifik ikan (Anderson, 1992). Pemberian immunostimulan secara luas dilakukan dengan maksud untuk mengaktifkan sistem imun non spesifik sel seperti makrofag pada vertebrata dan hemosit pada avertebrata (Dugger and Jory, 1999). Salah satu bahan alami yang dapat dipergunakan untuk imunostimulan adalah $S$. platensis (Simanjuntak, 2002). Spirulina platensis memiliki kandungan lipopolisakarida (LPS) (Tornabene et al., 1985). Lipopolisakarida adalah komponen dinding sel $S$. platensis yang dapat berfungsi sebagai imunostimulan. Masuknya imunostimulan ke dalam tubuh ikan dapat meningkatkan kinerja sel limfosit untuk membelah menjasi limfosit $\mathrm{T}$ dan B. limfosit $\mathrm{T}$ akan memproduksi interferon sehingga kemampuan makrofag meningkat dan proses memfagosit antigen akan meningkat. Menurut Boajiang (1994), kandungan Lipolisakarida (LPS) pada $S$. platensis dapat memperbaiki fungsi imunitas seluler non spesifik dan fungsi humoral spesifik. LPS merupakan bagian dari dinding sel $S$. platensis yang berfungsi pada respon kekebalan tubuh. LPS dapat mengiduksi Tool Like Receptor 4 (TLR4) yang berada pada permukaan sel sehingga sel leukosit yaitu neutrofil, monosit dan makrofag dapat mengenali dan mengikat LPS dan mengaktifkan interleukin IL-1, IL-6 dan TNF$\alpha$ yang kemudian akan mengaktifkan sel-sel lain yang terlibat dalam mekanisme pertahanan inang (Gallay et al., 1993).

Sistem kekebalan tubuh ikan terbagi atas sistem kekebalan spesifik dan non spesifik. Pertahanan non spesifik merupakan pertahanan tubuh terdepan terhapat serangan antigen yang masuk kedalam tubuh ikan sehingga dapat memberikan respon langsung terhadap antigen sedangkan sistem pertahanan spesifik membutuhkan waktu untuk mengenal antigen sebelum memberikan responnya (Baratawidjaja, 2006). Ikan memiliki beberapa tipe leukosit yang terlibat dalam pertahanan seluler ikan yaitu monosit, neutrofil dan limfosit. Monosit dan neutrofil berfungsi sebagai sel fagosit yang menangkap antigen dan mempresentasikan kepada sel penyaji atau APC (Antigen Presenting Cell). Proses ini disebut sebagai fagositosis yang efektif mencegah timbulnya infeksi. Sel fagosit akan berinteraksi dengan komplemen dan sistem imun spesifik (Baratawidjaja, 2006). Limfosit terdiri dari 2 tipe yaitu limfosit $\mathrm{T}$ dan limfosit B. Limfosit $\mathrm{T}$ akan memproduksi interferon dan meningkatkan kemampuan makrofag sehingga dapat memfagosit antigen yang masuk kedalam tubuh ikan. Limfosit B akan memproduksi antibodi yang akan bersirkulasi pada darah. Antibodi yang terbentuk akan menempel pada antigen asing dan mengkodenya supaya dapat dihancurkan oleh sistem imun (Raa et al., 1992).

Pada penelitian Tayag et al. (2010) pemberian ekstrak air panas $S$. platensis terhadap Litopenaeus vannamei dapat meningkatkan Aktifitas Phenoloxidase, respiratory burst $(\mathrm{RB})$, aktifitas superoxide dismutase (SOD), aktifitas glutathione peroxidise dan meningkatkan Survival rate dengan uji tantang dengan Vibrio alginotycus. Pada penelitian lain yaitu penelitian Watanuki 
et al. (2006) pemberian $S$. platensis secara oral pada ikan mas (Cyprinus carpio) dapat meningkatkan aktivitas fagositosis, meningkatkan ekspresi TNF- $\alpha$ dan menurunkan total bakteri A.hydrophila pada organ ginjal dan liver pada dosis $10 \mathrm{mg} / \mathrm{ikan}$. Berdasarkan latar belakang permasalahan yang telah dipaparkan di atas, maka perlu dilakukan penelitian untuk mengetahui pengaruh penambahan ekstrak $S$. platensis terhadap respon imun ikan gurame dengan beberapa parameter yang mempengaruhi sistem imun yaitu total leukosit, indeks fagositosis dan konsentrasi TNF- $\alpha$.

\section{METODE PENELITIAN}

\subsection{Persiapan air dan wadah}

Air diisikan pada bak tandon air kemudian disterilkan menggunakan larutan klorin 20 ppm diaerasi selama 24 jam kemudian ditambah Natrium thiosulfat $10 \mathrm{ppm}$ hingga bau klorin hilang. Akuarium sebanyak 12 buah dengan ukuran $30 \times 40 \times 30 \mathrm{~cm}$ yang dilengkapi dengan aerator, selang dan batu aerasi. Sebelum digunakan akuarium tersebut disuci hamakan dengan larutan chlorin selama 24 jam, kemudian diisi air steril dengan ketinggian air $25 \mathrm{~cm}$, dan diaerasi selama 24 jam.

\subsection{Adaptasi Ikan Uji}

Ikan gurame ukuran 7,5-8,5 $\mathrm{cm}$ yang berasal dari kelompok tani Tulungagung terlebih dahulu diadaptasikan selama 14 hari, kemudian ikan di ambil secara acak dan dimasukkan ke dalam wadah penelitian (akuarium), setiap akuarium di isi 12 ekor ikan. Selama adaptasi ikan diberi pakan yang sama dengan tempat pemeliharaan sebelumnya yaitu kangkung yang dicuci bersih dan pakan komersil dengan kadar protein. Pakan diberikan dengan frekuensi pemberian 2 kali sehari (pagi dan sore).

\subsection{Pembuatan ekstrak $S$. platensis}

Tepung S. platensis diperoleh dari Balai Besar Perikanan Budidaya Air Payau (BBPBAP) Jepara. Metode ekstraksi menggunakan air panas $S$. platensis adalah disusun berdasarkan metode yang dijelaskan
Tayag et al., 2010. Pembuatan ekstrak 20 gr tepung $S$. platensis ditambahkan ke $100 \mathrm{ml}$ air deionisasi, didihkan dan diaduk selama 1 jam dengan suhu $90^{\circ} \mathrm{C}$. Kemudian disentrifuge pada suhu $4^{\circ} \mathrm{C}$ dengan kecepatan $2500 \mathrm{rpm}$ selama 15 menit untuk memisahkan endapan dan supernatan, supernatan diambil dan disimpan pada botol kaca. Hasil supernatan dikeringkan dengan proses freeze drying dan didapatkan bobot kering sejumlah 3,382 gr.

\subsection{Perendaman ikan gurame dengan ekstrak air panas S. platensis}

Ikan yang digunakan dalam penelitian ini adalah ikan Gurame dengan ukuran 7,5-8,5 $\mathrm{cm}$ yang dipelihara dalam akuarium. Masingmasing akuarium diisi dengan 12 ekor ikan. Ikan diadaptasikan pada akuarium dan diberi pakan selama 14 hari. Pada hari ke 15 dilakukan perendaman dalam ekstrak dengan 3 perlakuan dosis yaitu $15 \mathrm{ppm}, 30 \mathrm{ppm}, 60 \mathrm{ppm}$ dan air steril selama 3 jam.

\subsection{Pengambilan Darah Ikan}

Pada hari 3, 5, 7 dan 14 setelah perendaman, ikan diambil darahnya. Masingmasing akuarium diambil darah dari dua ekor ikan. Sebelum sampling darah ikan dibius dengan menggunakan minyak cengkeh dengan dosis $1 \mathrm{ml} / 8$ liter air (Hastuti, 2007). Ikan dimasukkan dalam larutan minyak cengkeh sampai pingsan. Pengambilan darah melalui vena kaudal yang berada di pangkal ekor ikan menggunakan spuit ukuran $1 \mathrm{ml}$. Sebelumnya, jarum suntik dan tabung ependorf dibilas dengan larutan EDTA 10\% untuk mencegah pembekuan darah. Darah disimpan dalam mikrotube ukuran 1,5 ml. Sample diambil untuk pengujian total leukosit, indeks fagositosis dan glukosa darah.

Pengambilan darah untuk uji aglutinasi dan konsentrasi TNF- $\alpha$ dilakukan tanpa antikoagulan untuk dipanen serumnya. Sample darah dibiarkan pada suhu ruang hingga terpisah antara serum dan sel darah merah kemudian disimpan 24 jam pada suhu $5^{\circ} \mathrm{C}$ kemudian disentifuge dengan kecepatan $5000 \mathrm{rpm}$ selama 5 menit, kemudian serum dipanen dan disimpan pada suhu $-20^{\circ} \mathrm{C}$ hingga akan digunakan untuk analisa (Misra et al., 2006). Selanjutnya ikan yang telah diambil 
darahnya dikembalikan kedalam wadah yang berisi air bersih dengan aerasi hingga ikan pulih kesadarannya.

\subsection{Parameter uji}

\subsubsection{Total Leukosit}

Penghitungan jumlah leukosit yaitu darah dihisap dengan pipet yang berisi bulir pengaduk warna putih sampai skala 0,5 kemudian ditambahkan dengan larutan Turk's sampai skala 11. Darah dalam pipet diaduk dengan cara menggoyangkan pipet membentuk angka delapan selama 3-5 menit hingga tercampur dengan cata. Dua tetes pertama larutan darah dibuang dan tetes selanjutnya di teteskan pada haemocytometer yang telah diletakkan cover glass diatasnya. Jumlah leukosit dihitung dengan cara mengkonversikan dengan jumlah sel total kotak besar dan volume kotak sehingga didapat jumlah sel darah putih per $\mathrm{mm}^{3}$ (Blaxhall dan Daisley, 1973)

\subsubsection{Indeks Fagositosis}

Penghitungan nilai indeks fagositosis dilakukan menurut Anderson and Siwicki (1993). Sebanyak $50 \mu 1$ darah dimasukkan ke dalam mikrotiter plate, ditambahkan $50 \mu \mathrm{l}$ suspensi Aeromonas dalam PBS $\left(10^{8} \mathrm{sel} / \mathrm{ml}\right)$. Campuran darah dan bakteri dihomogenkan dan diinkubasi dalam suhu ruang selama 20 menit. Sebanyak $5 \mu \mathrm{l}$ campuran darah dan bakteri diambil untuk dibuat sediaan ulas darah. Pembuatan preparat ulas darah dilakukan menurut Svobodova and Vyukusova (1991). Preparat ulas darah yang telah dibuat selanjutnya diamati dengan menggunakan mikroskop perbesaran 1000x. Indeks fagositosis dihitung berdasarkan jumlah bakteri yang difagosit dibagi 100 sel fagosit yang terfagosit (Misra et al., 2006).

\subsubsection{Konsentrasi TNF- $\alpha$}

Penentuan konsentrasi TNF- $\alpha$ dengan metode ELISA diawali dengan pembuatan larutan standart TNF- $\alpha$ yang terdapat pada kit ELISA. Konsentrasi standar TNF- $\alpha$ yang dibuat adalah $240 \mathrm{ng} / \mathrm{L}, 120 \mathrm{ng} / \mathrm{L}, 60 \mathrm{ng} / \mathrm{L}, 30$ ng/L, $15 \mathrm{ng} / \mathrm{L}, 7,5 \mathrm{ng} / \mathrm{L}$ pada tabung reaksi dibuat sebanyak 2 ulangan, larutan yang telah siap disimpan untuk proses selanjutnya. Pada lubang larutan standar masukkan masingmasing $50 \mu \mathrm{l}$ standar dan $50 \mu \mathrm{l}$ streptavidin
HRP. Pada masing-masing lubang sampel masukkan $40 \mu \mathrm{l}$ sampel dan $10 \mu \mathrm{l}$ antibodi TNF- $\alpha$. Tutup mikroplate dengan plate membran kemudian goyang hingga tercampur. Inkubasi pada $37^{\circ} \mathrm{C}$ seama 60 menit. Siapkan larutan pencuci dan diencerkan menggunakan aquabides sebanyak 30x. Cuci masing-masing lubang dengan larutan pencuci. Keringkan selama 30 detik kemuadian ulangi prosedur pencucian hingga lima kali. Tambahkan 50 $\mu$ l larutan chromogen A pada masing-masing lubang dan diikuti penambahan larutan chromogen B sebanyak 50 $\mu$ l. Goyang hingga homogen. Inkubasi selama 10 menit pada suhu $37^{\circ} \mathrm{C}$. Tambahkan larutan stop sebanyak $50 \mu 1$ pada masing-masing lubang hingga warna biru berubah menjadi warna kuning. Absorbansi diukur pada panjang gelombang 450nm. Konsentrasi TNF- $\alpha$ dapat diukur dengan bantuan persamaan regresi linier pada kurva standar.

\section{HASIL DAN PEMBAHASAN}

Hasil penelitian menunjukkan bahwa ikan gurame yang diberi immunostimulan ekstrak air panas S. platensis yang mengandung polisakarida mampu menstimulasi sistem imun non spesifik ikan gurame melalui peningkatan jumlah leukosit. Hal ini dapat dilihat pada perlakun B hari ke lima terjadi peningkatan sampai hari ke 14 yaitu $142,333 \times 10^{5} \mathrm{sel} / \mathrm{mm}^{3}$ pada hari ke lima dan meningkat $409,292 \times 10^{5} \mathrm{sel} / \mathrm{mm}^{3}$ pada hari keempat belas. Hal ini sesuai dengan penelitian Selvaraj et al., (2007) Pemberian lipopolisakarida sebagai imunostimulan pada C. carpio dapat meningkatkan respon imun nonspesifik yaitu dapat meningkatkan total leukosit pada hari ke tiga sampai hari kelima selama penelitian.

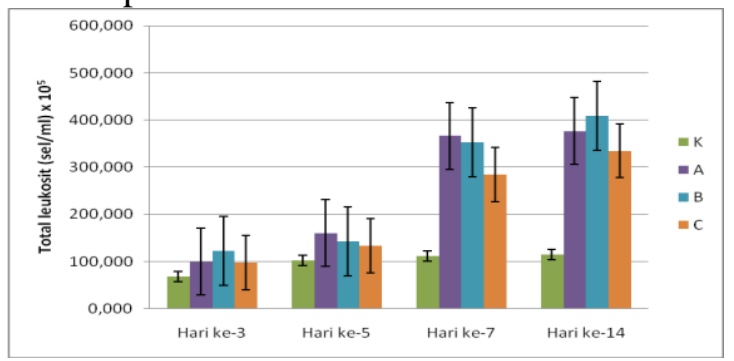

Gambar 1. Grafik rata-rata total leukosit selama penelitian 
Peningkatan total leukosit pada ikan menunjukkan bahwa sistem pertahanan tubuh ikan meningkat, karena dengan meningkatnya jumlah total leukosit akan memberikan perlindungan ikan bila ada serangan infeksi patogen. Perubahan jumlah total leukosit dapat dijadikan indikator adanya infeksi tertentu pada ikan, produksi leukosit akan meningkat akibat respon adanya inflamasi dan infeksi. Aktivitas fagositik yang dilakukan oleh sel-sel leukosit akan meningkat pada awal infeksi dan mengalami penurunan pada infeksi kronis (Anderson et al., 1995). Sistem leukosit dan sel-sel jaringan dari leukosit bekerja dengan dua cara untuk mencegah penyakit yaitu dengan cara merusak melalui proses fagositosis dan membentuk antibodi. Peningkatan jumlah sel darah putih merupakan respon dalam bentuk proteksi terhadap adanya sel asing termasuk adanya infeksi bakteri yang masuk ke tubuh ikan. Hasil produksi leukosit akan diarahkan menuju daerah terinfeksi sebagai pertahanan ikan. Naiknya jumlah leukosit merupakan indikator adanya infeksi yang mengakibatkan terjadinya inflamasi (Harikrishnan et al., 2010).

Hasil penghitungan indeks fagositosis pada penelitian ini menunjukkan peningkatan setiap hari. Pada penelitian ini perlakuan B (30 ppm) dapat meningkatkan indeks fagositosis pada hari ke tiga yaitu sebesar $32 \%$ dan meningkat pada hari keempat belas yaitu $68,667 \%$.

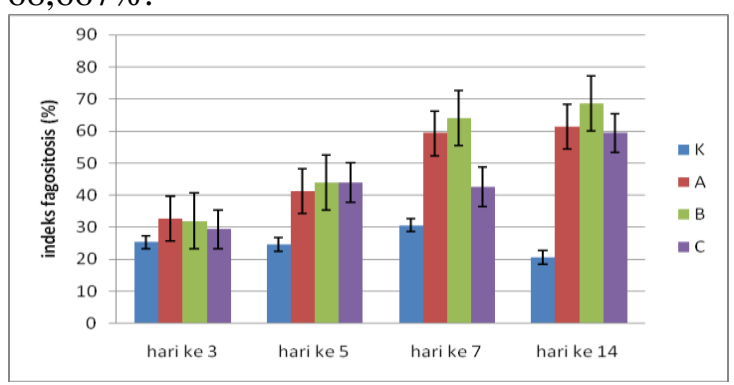

Gambar 2. Grafik rata-rata indeks fagositosis selama penelitian

Hal ini sesuai dengan penelitian Watanuki et al., (2006) yang memberikan $S$. platensis secara oral dapat meningkatkan aktivitas fagositosis pada ikan $C$. carpio pada dosis $10 \mathrm{mg} / \mathrm{ikan}$. Pada penelitian Setyowati (2003) pemberian $S$. platensis sebagai imunostimulant yang diberikan melalui pakan dapat meningkatkan indeks fagositosis ikan Gurame dengan dosis 4\% dibandingkan dengan kontrol LPS Vibrio harveyi 0,06 \%.

Pola peningkatan prosentase indeks fagositik ini merupakan fungsi dari peningkatan total leukosit maupun presentasi jenis leukosit masing-masing pada limfosit, monosit dan neutrofil (Amrullah, 2005). Aktivitas fagositosis menunjukkan jumlah total dari sel fagosit yang aktif dibandingkan dengan jumlah sel fagosit yang teramati. Proses fagositosis menurut Spector (1993) terjadi apabila terjadi kontak antara partikel dengan permukaan sel fagosit. Proses fagosit sendiri dapat terjadi apabila sel-sel fagosit berada dalam jarak dekat dengan antigen, atau antigen tersebut harus melekat pada permukaan sel fagosit (Neumann et al., 2001). Sel makrofag dan netrofil juga masih memiliki kemampuan untuk melakukan mekanisme pertahanan non-spesifik melalui proses chemotaksis dan pinocytosis. Sementara itu Baratawijaya (1991) menyebutkan bahwa penghancuran kuman oleh fagositosis terjadi dalam beberapa tingkat yaitu kemotaksis dimana sel sel fagositosis mendekati mikroorganisme, kemudian menangkap, memakan (fagositosis), membunuh dan mencerna.

Pada penelitian ini konsentrasi B dengan dosis $30 \mathrm{ppm}$ yang diambil sampelnya pada hari ke tujuh dapat meningkatkan konsentrasi TNF- $\alpha$ terbaik yaitu sebesar $38,851 \mathrm{ng} / \mathrm{L}$ hal ini sesuai dengan penyataan Savan and Sakai (2004). Lipopolisakarida (LPS) dapat menstimulasi ekspresi dari TNF$\alpha$ pada kepala ginjal ikan carp. TNF- $\alpha$ merupakan mediator utama pada respons terhadap bakteri gram negatif dan berperan dalam respon imun bawaan. TNF- $\alpha$ diproduksi oleh makrofag, pembentukannya terjadi akibat rangsangan dari bakteri, virus atau sitokin lain misalnya IL-1, IL-2 dan IFN- $\gamma$. TNF- $\alpha$ memiliki beberapa fungsi dalam sebagai berikut: mengatur aktivasi makrofag dan respon imun jaringan yaitu dengan merangsang sitokin lain dan berfungsi sebagai regulator dari hematopoetik serta komitogen 
untuk sel $\mathrm{T}$ dan sel B serta aktivasi sel neutrofil dan makrofag (Roitt et al., 2001). LPS merupakan rangsangan poten untuk mensekresi TNF- $\alpha$. IFN- $\gamma$ yang diproduksi oleh sel $\mathrm{T}$ dan sel NK juga merangsang makrofag antara lain meningkatkan sintesis TNF- $\alpha$. (Pool et al., 1997).

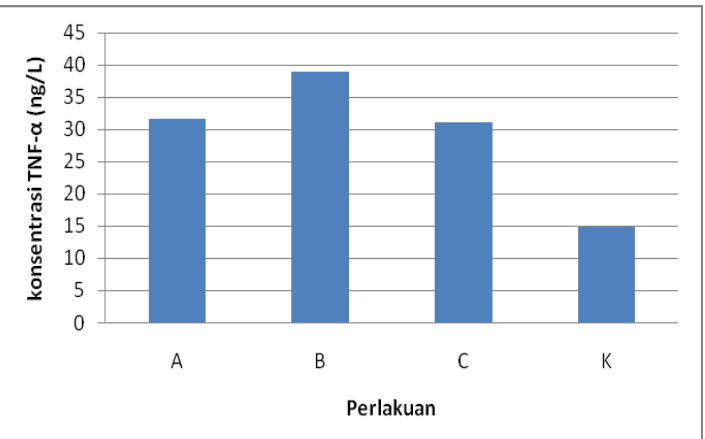

Gambar 3. Grafik rata-rata konsentrasi TNF$\alpha$ selama penelitian

Pada hasil penelitian terlihat bahwa perlakuan A dan B (pemberian ekstrak air panas $15 \mathrm{ppm}$ dan $30 \mathrm{ppm}$ ) lebih tinggi dibandingkan dengan perlakuan $\mathrm{C}$ (pemberian ekstrak air panas $60 \mathrm{ppm}$ ). Ini menunjukkan bahwa pemberian ekstrak air panas $S$. platensis pada dosis yang lebih tinggi mengakibatkan terjadinya penurunan fungsi sistem imun ikan (immunosupresi atau efek balik negatif) Pemberian ekstrak air panas $S$. platensis yang mengandung lipopolisakarida pada penelitian ini dapat meningkatkan total leukosit, indeks fagositosis dan TNF- $\alpha$. Total leukosit, indeks fagositosis dan TNF- $\alpha$ pada ikan gurame dapat memberikan peningkatan respons imun dan peningkatan perlindungan terhadap serangan infeksi patogen. Hal tersebut sejalan dengan hasil penelitian Selvaraj et al. (2005) yang memberikan Lipopolisakarida secara injeksi sebanyak 100 $\mu \mathrm{g} / \mathrm{ml}$ pada $C$. Carpio yang dapat menstimulasi penngkatan total leukosit, diferensial leukosit, peningkatan ekspresi IL- $\beta$ dan resistensi ikan mas (Cyprinus carpio) terhadap infeksi A. hydrophilla.

Kondisi kualitas air selama penelitian masih mendukung kelangsungan hidup ikan gurame. Faktor lingkungan yang mendukung kelangsungan hidup ikan gurame antara lain suhu air, $\mathrm{pH}$, amoniak dan kandungan oksigen telarut. Suhu air selama penelitian dalam rentang $29-30^{\circ} \mathrm{C} . \mathrm{pH}$ air selama penelitian berkisar antara 7,5-8. Oksigen terlarut selama penelitian rentang 6-8. Kandungan ammonia terlarut sebesar $0,5-0,52 \mathrm{mg} / \mathrm{l}$. SNI menyatakan ikan gurame dapat hidup dalam rentang suhu sekitar $27-30^{\circ} \mathrm{C}$, pH sekitar 7,58,5 dan kandungan oksigen terlarut >3-7.

\section{KESIMPULAN}

Pemberian ekstrak air panas S. platensis mampu meningkatkan total leukosit ikan gurame dengan dosis terbaik yaitu $30 \mathrm{ppm}$ yaitu sebesar $409,292 \times 10^{5} \mathrm{sel} / \mathrm{mm}^{3}$, indeks fagositosis ikan gurame dengan dosis terbaik yaitu 30 ppm yaitu sebesar $68 \%$ dan meningkatkan konsentrasi TNF- $\alpha$ ikan gurame dengan dosis terbaik yaitu $30 \mathrm{ppm}$ yaitu sebesar 38,851 ng/L pada hari ke empat belas

\section{SARAN}

Perlu dilakukan penelitian lanjutan mengenai kemampuan ekstrak air panas $S$. platensis dalam meningkatkan ketahanan tubuh ikan gurame terhadap seranganpenyakit yaitu dengan melakukan uji tantang menggunakan bakteri, virus maupun patogen lainnya.

\section{DAFTAR PUSTAKA}

Anderson, D.P. dan Swicki A.K. 1992. Injection or Immersion Delivery of Selected Immunostimulant to Trout Demonstrate Enhancement of Non Specific Devence Mechabism and Protective Immunity in Discus in Asian Aquaculture II. Sharif, M.J. Fish Health Section Asian Sociaty, p. 413- 426

Anderson, D.P. and A. K. Siwicki. 1993. Basic Hematology and Serology for Fish Health Program. Paper Presented in Second Symposium on Diseases in Asian Aquaculture "Aquatic Animal Health and The Environment" Phuket Thailand. 25-29 Oct 1993. 17 p. 
Baratawidjaja, K. G. 2006. Imunologi Dasar Edisi Ke Tujuh. Jakarta: Balai Penerbit FKUI.

Blaxhall PC, Daisley KW. 1973. Routine haematological methods for use with fish blood. J. Fish Biology 5:577-581

Boajiang, G. 1994. Study on Effect and Mechanism of Polysaccharida of Spirulina platensis on Body Immune Function Improvement. Book of Abstracts. Second Asia Pacific Conference on Algal Biotechnology. p. 24.

Dugger, D.M., Jory, D.E. Bio-modulation of the nonspecific immune response in marine shrimp with betaglucan. Aquaculture Magazine, v. 1, p. 8189, 1999.

Gallay, P., Heumann, D., Roy, D.L., Barras, C. and Glauser,M.P.. 1993. Lipopolysaccharide-binding protein as a major plasma protein responsible for endotoxemic shock. Proceedings of the National Academy of Sciences (USA) 90: 9935-9938.

Harikrishnan, R., Balasundaramb, C., Heo, M.S. 2010. Effect of probiotics enriched diet on Paralichthys olivaceus infected with lymphocystis disease virus (LCDV). Fish \& Shellfish Immunology. 29: 868-874.

Hastuti, S. D. 2007. Evaluation of non-specific defence of Tilapia (Oreochromis sp.) injected with LPS (Lipopolysaccharides) of Aeromonas hydrophilla. Jurusan Perikanan, Fakultas Peternakan - Perikanan, Universitas Muhammadiyah Malang. Vol.14.No.1.Th.2007

Kamiso H.N dan Triyanto. 1993. Vaksinasi $A$. hydrophila untuk Menanggulangi Penyakit MAS pada Lele Dumbo. Abstrak. Simposium Perikanan Indonesia I. Jakarta.

Misra, C.K. 2006. Growth, non spesific immunity and disease resistance of Labeo horita against A. Hydrophila in biofoc systems using diferent carbon sources. Fish and shellfish immunology vol. 20 305-319.
Neumann H. 2001. Control of glial immune function by neurons. PubMed: ;36:191-199.

Roitt. I, Brostoff J, Male D. 2001. Cytokines and cytokines receptors in Immunology sixth edition Billiere Tindall, Churchill. Livingstone. Mosby WB Saunders, p.119-129.

Savan, R., Sakai, M. 2004. Presence of multiple isoforms of TNFalpha in carp (Cyprinus carpio L): genomic and expression analysis. Fish Shellfish Immunol. 17, 87-94.

Simanjuntak, S. B. I. 2002. Histologi Organ Limphoid Ikan Patin Jambal (Pangasius djambal Bleeker) yang Diberi Immunostimulan Spirulina. Thesis. Program Pascasarjana. Institut Pertanian Bogor. Bogor, 62 p.

Selvaraj.V., K. Sampath and V. Sekar. 2005. Administration of lipopolysaccharide increases specific and non-specific immune parameters and survival in carp (Cyprinus carpio) infected with Aeromonas hydrophila. Journal fish and shellfish immunology 176-183.

Setyowati, E.K. 2003. Potensi Spirulna platensis sebagai Immunostimulan pada Ikan Gurame. Thesis. Program Pascasarjana. Institut Pertanian Bogor. Bogor.

Svobodova, Z., Vyukusova, B., 1991. Diagnostic, Prevention and Therapy of Fish Disease and Intoxication. Research Institute of Fish Culture and Hydrobiology Vodnany Czechoslovaki.

Tayag, C.M., Y.C. Lin., C.H. Liou and J.C. Chen. 2010. Administration of the hot-water extract of Spirulina platensis enhanced the immune response of white shrimp Litopenaeus vannamei and its resistance against Vibrio alginolyticus. Journal fish and shellfish immunology 764-773. 
Jurnal Biosains Pascasarjana Vol. 18 (2016) pp

(C) (2016) Sekolah Pascasarjana Universitas Airlangga, Indonesia

Tornabene. T.G.,Bourne, T.F., Raziuddin.S., Ben-Amotz. A. 1985. Lipid and lipopolysaccharide constituents of cyanobacterium Spirulina platensis (Cyanophyceae, Nostocales). Mar. Ecol.prog. ser 22:121:125

Watanuki, H., K. Ota., A.C. Malina., T. Kato., M. Sakai. 2006. Immunostimulant effects of dietary Spirulina platensis on carp Cyprinus carpio. Aquaculture 157-163 